\title{
The Russian Past and the Socialist Future in the Thought of Peter Lavrov
}

The major ideological challenge faced by Russian revolutionists in the half century prior to 1917 was to find a way to adapt the principal tenets of West European socialism to Russia. The difficulty of answering this challenge lay in Russia's unique historical development and the consequent differences between Russia and the West. The proper adaptation of socialism required an understanding of these differences and their significance.

Revolutionary polemic and the historiographical tradition that it spawned have created an impression that pre-Marxist revolutionists, the so-called populists (narodniki), ${ }^{1}$ idealized the unique features of Russia, particularly the native socialism of the peasant and his ancient, uncorrupted commune or obshchina. The romantic populist found Russia superior to and potentially more advanced, more "socialistic," than the West precisely because of her historical backwardness, the survival of a primitive agricultural communal tradition, and the happy absence of most distinctive economic and social features of industrial, bourgeois Western Europe. The populist supposedly dreamed of a unique peasant utopia made possible by the obshchina. ${ }^{2}$ Although

1. The term "populism" is like most "isms." It has only the broadest prescriptive meaning. Marxism, with all its varieties and factions, has a more precise meaning; at least it has locus in the tangible, written work of one scholar-activist (Marx) and his collaborator (Engels). Populism is an elastic term traditionally applied to a vast range of views and movements, ranging from the 1840 s into the twentieth century, from the aristocratic litterateur and journalist, Alexander Herzen, to the terrorist of peasant stock, Alexei Zheliabov, from conservatives to revolutionists. Any attempt to give the term specific meaning must be tentative and skeptical. Any pretense to precise or absolute usage must exclude more than it includes, must obscure more than it illuminates. Witness the first chapter of Andrzej Walicki's The Controversy Over Capitalism (Oxford, 1969). The term was scarcely used at all in the years of most intense "populist" revolutionary activity, the 1870s. "Populism" has often been used freely and anachronistically to apply to men and movements that did not know the term.

2. See Sovetskaia istoricheskaia entsiklopediia, s.v. "Narodnichestvo," 9:922-23, where populism is described as "a special variety of utopian socialism. . . . The main substance of the theory of Russian utopian socialism is the faith in the possibility of a direct transition-passing over capitalism-to socialism by means of the peasant obshchina

This article grew out of work on a monograph on the political career of Peter Lavrov, and is an extensively revised version of a paper presented to the Bi-State Slavic Conference in November 1968. I would like to thank the several people who have read this paper and given advice, especially Val Lorwin, Nicholas Riasanovsky, Peter Christoff, and Boris Sapir. 
the polemical fog seems to be lifting from the early phases of the Russian revolutionary socialist movement, especially the most important decade, the 1870s, the traditional image of the Slavophilistic, romantic narodnik lingers. ${ }^{3}$

No ideologist had more influence on the Russian revolutionary movement in its early stages than Peter Lavrov. ${ }^{4}$ Yet his analysis of the historical development and nature of Russian society bears little resemblance to the traditional image of populism. He elaborated an explanation of Russia's special historical development which allowed him the hope that rural Russia might join the anticipated world-wide socialist upheaval. He recognized that certain peculiar features set his homeland off from the West. But he did not idealize these peculiar features. The Russian past, in fact, was responsible for a series of social and political weaknesses unknown to the West. Yet the situation was not hopeless. Lavrov felt that his own time presented an opportunity for Russia to rejoin European civilization in the quest for the socialist future.

The carefully balanced relationship which Lavrov was able to establish between the special conditions of Russia and general European socialist doctrines is as distinctively characteristic of his revolutionary ideology as the inspiration of "critical-minded individuals" is of his broader ethical teachings. He adhered to his analysis of Russian historical development from the earliest moments in his revolutionary career in the 1870 s until his death in $1900 . \mathrm{He}$ publicized this analysis in his journal Vpered! (Forward!), which was circulated widely in Russia and among Russian émigrés during the most critical

which is assigned a special role." Returning to the source, the article quotes Lenin, who wrote that the fundamental characteristic of populism was "faith in a special configuration, in the communal [obshchinnyi] structure of Russian life."

3. Many examples could be cited; two will suffice. Janko Lavrin, "Populists and Slavophiles," Russian Review, 21, no. 4 (October 1962):307-17, refers to populism as "secularized Slavophilism-with due reservations, of course." But, reservations aside, both populists and Slavophiles "cherished a sincere love" for the unique "social" and "moral" significance of the peasant masses: "The populists, no less than the Slavophiles, hated the character of the capitalist Western civilization" and were as one in their "idealization of the obshchina." Isaiah Berlin's introduction to Franco Venturi's monumental Roots of Revolution (London and New York, 1960), p. xxviii, concludes that all populists, of whatever shade, were "dominated by a single myth: that once the monster was slain, the sleeping princess-the Russian peasantry-would awaken and without further ado live happily for ever after."

4. Leonid Shishko, who was active in the Russian movement from his youth (1873) until his death (1910), has maintained that Lavrov's influence was greater than Bakunin's. Bakunin, of course, made a strong impression on the Russian movement, but his influence was very brief, in essence only 1872-76; see P. S. Tkachenko, Revoliutsionnaia narodnicheskaia organizatsiia "Zemlia i Volia" (1876-1879 gg.) (Moscow, 1961), p. 39. Tkachenko cites evidence to support Shishko's position. He emphasizes the broad and enduring influence of Lavrov's revolutionary thought. Vpered!, for example, "played a great role in the formation of the revolutionary consciousness not only of its strict adherents but even of those who stood far from the Lavristic position." Tkachenko rightly and regretfully notes that Lavrov's influence on the Russian revolutionary movement remains almost totally neglected. 
period in the early history of Russian revolutionary socialism. ${ }^{5}$ In small seminars in his Paris apartment, in the European socialist press, and in Russian revolutionary journals of the last three decades of the nineteenth century, he continued to reach a wide audience on the question of Russia's peculiar past and its revolutionary socialist meaning. ${ }^{6}$

5. Vpered / was published in periodical and nonperiodical editions from 1873 to 1877 , from the "going to the people" until the formation of the revolutionary organization Land and Liberty. Around two thousand copies per volume of the nonperiodical edition of $V$ peredl were published. In response to the significant increase in demand and circulation, the periodical edition increased production from two thousand copies per semimonthly issue in 1875 to three thousand per issue in 1876. The journal experienced a sharp increase in popularity when it shifted attention from the more academic issues ("knowledge and revolution," etc.) to the hard-core problems of social analysis and revolutionary tactics. Testimony delivered at the two major trials of revolutionary activists in the 1870 s reveals that Vpered! was widely distributed throughout Russia and was read with care. The journal had a prominent place in the libraries of underground organizations in St. Petersburg, Moscow, Kiev, Tula, Kharkov, Taganrog, Orenburg, Poltava, Samara, Nikolaevsk, and many other important centers of revolutionary activity. See Protsess 50-ti (London, 1877) and Protsess 193-kh (Moscow, 1906). On occasion, an especially important lead article would be hectographed for wider use (Protsess 193-kh, p. 127).

6. In addition to his major articles on this topic, listed in notes 11 and 15 , Lavrov communicated his views throughout the last thirty years of his life in many places and publications. His apartment became a mecca for recently emigrated Russian radicals. There he conducted "seminars" on socialism which were attended by many future activists in the Russian movement (see my article on Plekhanov and Lavrov in 1877, to be published by the Academy of Sciences of the USSR in a sbornik on populism). And he continued to write on topics related to the international revolutionary movement. $\mathrm{He}$ was close to the editorial board of the French Marxist journal L'Égalité, which first appeared in November 1877, edited by Jules Guesde and supported by César de Paepe and Benoit Malon. Later he was close to Clemenceau's Justice in 1880. In that year Plekhanov drew close to Lavrov again, and soon Lavrov was, de facto if not de jure, a member of the "Chernyi peredel" group. He wrote the important programmatic article, "Neskol'ko slov ob organizatsii partii," for their journal, Chernyi peredel, no. 3 (1880).

When Plekhanov's group broke off relations with the People's Will in 1883, Lavrov chose to stay with that group, which he felt was prepared to continue the actual (as opposed to the theoretical) revolutionary cause. Lavrov became coeditor, with Lev Tikhomirov, of the major journal of the Russian revolutionary movement of the 1880s, Vestrik "Narodnoi voli," from 1883 to 1886 . His published lecture, Natsional'nost" i sotsializm (Geneva, 1887), was widely read. When the socialist movement began to stir again in the late 1880s, after almost ten years of decline, Lavrov was near the center of action. $\mathrm{He}$ wrote important programmatic articles for the journals Samoupravlenie ("Pis'mo v redaktsiiu P. Lavrova," no. 2, 1888) and Sotsialist ("Pis'ma k russkim liudiam," no. 1, 1889). He was the most highly esteemed Russian at the founding congress of the Second International in 1889; see Istoriia vtorogo internatsionala, 1 (Moscow, 1965): 144. When the central journal of the German Social Democratic Party, Vorwärts, was revived in 1891, Lavrov was invited to write on the Russian movement; see especially his series of articles, "Die revolutionären Strömungen in Russland," Vorwärts, nos. 107, 127, and 163 (May 10, June 4, and July 16, 1891). He remained a staunch supporter of the international socialist movement until his death. And he also remained in contact with Russian affairs. He was one of the organizers and leaders of the radical Committee for the Struggle with Hunger, with Plekhanov and P. B. Axelrod, 
No prominent Russian socialist except George Plekhanov had a longer or more sustained career of revolutionary journalism. Lavrov's influence has yet to be assessed accurately and in detail. Even so, it is clear that it was deep and long-lasting. It is generally known that he inspired a whole generation of "critical-minded individuals" with his Historical Letters, written in $1868-69$, before he joined the revolutionary cause. But it is not widely realized that his specifically and openly revolutionary writings also left a heavy imprint on the Russian movement.? No one man can be taken to be "typical" of the

in 1891-92. Lavrov helped launch one of the first journals of the future Socialist Revolutionary Party, Russkii rabochii, in 1894. And in response to a request for guidance on political issues, he wrote a long and detailed account of the current status and future needs of the Russian movement, "P. L. Lavrov o programnykh voprosakh," Letuchii listok Narodovol'tsev, no. 4 (Dec. 9, 1895). He was the core of a Paris-based group of "Old Narodovoltsy," and he coordinated and wrote part of their sixteen-volume Materialy dlia istorii russkago sotsial'no-revoliutsionnago dvizheniia (Geneva, 1893-96).

7. Strong and extensive evidence exists which indicates that Lavrov directly influenced almost every facet of the Russian revolutionary socialist movement from the 1870 s until his death. For his influence on the movement in the 1870 s, see M. G. Sedov, "P. L. Lavrov v revoliutsionnom dvizhenii Rossii," Voprosy istorii, 1969, no. 3, pp. 55-72; B. S. Itenberg, Dvizhenie revoliutsionnogo narodnichestva (Moscow, 1965), pp. 194-217; M. M. Karpovich, "P. L. Lavrov and Russian Socialism," California Slavic Studies, 2 (1963) : 21-38; T. M. Kirichenko, "K voprosu ob obshchestvenno-politicheskikh vzgliadakh P. L. Lavrova v 70-80-kh godakh XIX v.," Trudy Moskovskogo gosudarstvennogo istoriko-arkhizmogo instituta, 18 (1963): 443-63; and I. Knizhnik-Vetrov, P. L. Lavrov (Moscow, 1930).

Lavrov's important role in the emergence of Russian Marxian socialism has yet to be assessed properly; on Plekhanov, see note 6 and Plekhanov's letters to Lavrov in 1880-81, in L. G. Deich, ed., G. V. Plekhanov: Materialy dlia biografii (Moscow, 1922), $1: 79$ and 87 ; on Lavrov's general influence on the development of Marxism, see, for example, Iu. M. Steklov, Otkazyvaemsia li my ot nasledstva? $K$ voprosu ob istoricheskom podgotovlenii russkoi sotsial-demokratii (Geneva, 1902). P. B. Axelrod, who began his career as a Lavrist, credited Lavrov with introducing certain elements of Marxism and Social Democracy to Russia; see his Rabochee dvizhenie i sotsial'naia demokratiia (Geneva, 1884). It can be said that Lavrov "prepared the ground" for the eventual predominance of German Social Democratic ideas in the movement; see Boris Sapir, "Unknown Chapters in the History of 'Vpered,' International Review of Social History, 2 (1957): 53. The first Marxist group inside Russia, formed by the Bulgarian Dmitrii Blagoev, received as much inspiration from Lavrov as from any other Russian source; see A. Shnitman, "K voprosu o vliianii russkogo revoliutsionnogo dvizhenie v Bolgarii," Voprosy istorii, 1949, no. 1, p. 40; D. Labelle, "Dmitrii Blagoev in Russia: An Autobiographical Letter," International Review of Social History, 9 (1964): 286-97; and Iz arkhiva P. B. Aksel'roda (Berlin, 1924), p. 108.

Lavrov's association with and influence on the Northern Union of Russian Workers and the Southern Russian Union of Workers, the two most important workers' organizations in the 1870s, are attested to in V. I. Nevsky, Ot "Zemli i Voli" $k$ gruppe "Osvobozhdenie Truda" (Moscow, 1930), esp. pp. 136-37 and 170-74; O. V. Aptekman, Iz istorii revoliutsionnogo narodnichestva (Rostov on the Don, ca. 1909), pp. 78-79; M. P. Skveri, Pervaia rabochaia sotsialisticheskaia organizatsiia v Odesse (1875 god) (Odessa, 1921), pp. 45-50; and B. S. Itenberg, "Iuzhnorossiiskii soiuz rabochikh"-pervaia proletarskaia organizatsiia v Rossii (Moscow, 1954), pp. 40-41. Although the 1880s were not lively years in the movement, Lavrov continued to have some influence on the radical $k r u z h k i$ in the capitals; see I. I. Popov, "Revoliutsionnye organizatsii v Peterburge 
heterogeneous revolutionary socialist movement we have come to call populism. But Lavrov's influential ideology is witness to the great differences between early revolutionary socialism ("populism") and Slavophilism, and is indicative of the vital links between the "populist" and Marxist phases of the Russian revolutionary movement. The traditional image of the romantic narodnik is in need of extensive re-evaluation. The manner in which the early Russian revolutionary movement met the major ideological challenge of its epoch is worthy of a serious second look.

Lavrov was favorably inclined toward European socialist ideas and programs from an early date. ${ }^{8}$ Initially, however, he could not see how these ideas and programs applied to Russia. He did not commit himself fully to the revolutionary socialist movement until his forty-eighth year while he was an émigré in France. In 1870 he enlisted in a Paris section of the International Workingmen's Association. He received his baptism by fire in the Paris Commune. He entered the revolutionary movement as a firm adherent of European international socialism and, consequently, did not think of himself primarily as an émigré Russian socialist. ${ }^{\circ}$ When he reluctantly agreed,

v 1882-1885 godakh," Narodovol'tsy posle Iogo Marta 1881 goda (Moscow, n.d.), esp. pp. 49-55; and P. S. Tkachenko, Moskovskoe studenchestvo v Rossii vtoroi poloviny $X I X$ veka (Moscow, 1958), p. 152.

Lavrov was one of the ideological fathers of the Socialist Revolutionary Party; see Stepan Sletov, $K$ istorii vozniknoveniia partii sotsialistov-revoliutsionerov (Petrograd, 1917), esp. pp. 29 ff.; and P. Nagortsev, "Lavrov kak teoretik sotsializma," Sotsialist revoliutsioner, no. 1, 1910, pp. 151-78. Lavrov's role in the development of the socialist movement in Eastern Europe should be noted; for example, see E. K. Zhigunov and E. B. Rashkovsky, "Iz istorii russko-pol'skikh revoliutsionnykh sviazei 1878-1880 gg. (P. L. Lavrov i pol'skie sotsialisty)," in Obshchestvennoe dvizhenie v poreformennoi Rossii (Moscow, 1965), pp. 275-99; and W. D. McClellan, Svetozar Markovic and the Origins of Balkan Socialism (Princeton, 1964), pp. $188 \mathrm{ff}$. Lavrov learned a great deal from West European socialist literature, and, in turn, his socialist humanism and vast erudition had measurable impact on the French movement, on Lucien Herr and, through Herr, on Jean Jaurès; see Georges Lefranc, "Contribution à l'histoire du socialisme en France dans les dernières années du XIXe siècle: Léon Blum, Lucien Herr, et Lavrov," Information historique, September-October 1960; and Charles Rappoport, Jean Jaurès, l'homme, le penseur, le socialiste (Paris, 1925), especially the introduction. Despite the exaggerations normal in such documents, the extensive obituary which appeared in the important French radical periodical Le Mouvement socialiste, Feb. 15, 1900, pp. 193-99, and Mar. 1, 1900, pp. 274-86, might be quoted: "Dans le mouvement révolutionnaire de la seconde moitié de ce siècle, Lawroff est, après Marx, la figure la plus marquante et la plus élevée, autant par ses travaux et sa contribution au développement de la théorie socialiste, que par le rayonnement de sa personnalité morale et intellectuelle" (p. 194).

8. "P. L. Lavrov o sebe samom," Vestnik Evropy, no. 11, 1910, pp. 98-99.

9. Lavrov enrolled as a member of the Ternes Section of the First International, wrote a series of popular, scientific brochures for the International in Paris, and actively participated in meetings. See G. N. Vyrubov, "Revoliutsionnyia vospominaniia (Gertsen, Bakunin, Lavrov)," Vestnik Evropy, no. 2, 1913, pp. 60-61; and M. P. Sazhin, Vospominaniia, 1860-1880 gg. (Moscow, 1925), p. 35. Lavrov was very close to César de Paepe and other supporters of the Brussels journal L'Internationale, and he wrote for that journal. Both on the eve of the founding of the Paris Commune and after its fall, Lavrov 
in 1872 , to become editor of $V$ pered! he did so as a member of the international movement.

In accord with his socialist outlook, Lavrov recognized the progressive role in the West of capitalist industry and bourgeois civilization, "objective conditions" for the eventual firm achievement of socialism. The "miracle of steam and electricity," as he called it, was transforming everything. ${ }^{10}$ Capitalism had evolved slowly in the West, accompanied by a rich and complex process of scientific discoveries and inventions and by a gradual assimilation of political habits and social practices. This historical process had progressively transformed European civilization from top to bottom.

Looking back to earlier epochs Lavrov pointed to productive features of the distant feudal past from which modern European civilization had taken its origins. The Latin Church provided a unifying language, a high intellectual and spiritual culture, a powerful juridical tradition, the rigor of scholastic philosophy, and a continual, beneficial check on secular authority. Lavrov was especially impressed by the evolution in the West of a concept of natural law, above and independent of the crown. Society was protected by a tradition of "legality" which served as an important instrument in the history of European development and promised to serve the socialist revolution in a similar fashion. Within feudal society habits of class solidarity were based on legally protected class interests. The aristocracy and bourgeoisie benefited equally. Simultaneously, the class coherence of the proletariat was also strengthened. The evolution of feudal society created a prosperous peasantry and a secular urban culture with active craft and merchant guilds.11

conceived a plan to enter more actively into European socialist literary life. To a close friend he described a project which required that he write in French, live where French was spoken, and, more important, maintain personal contact "with individuals from that sphere for which the work is intended," that is, with the European socialist movement ("Pis'ma k E. A. Shtakenshneider iz Parizha v 1870-73 gg.," Golos minuvshego, 1916, no. 7-8, pp. 123-24).

10. "Istoriia i russkie revoliutsionery" (an unpublished article, dated July 31, 1887, a manuscript copy of which is held in the Hoover Institution at Stanford University), pp. $9-10$.

11. Lavrov expressed views on Western Europe in several key studies. Early adumbrations of his later views can be seen in the Foreign Courier (Zagranichnyi vestnik), of which he was editor (1864-66), and in his important programmatic article for the journal Bibliographer (Bibliograf) in 1869; see Bert Andréas, Le Manifeste Communiste de Marx et Engels: Histoire et Bibliographie, 1848-1918 (Milan, 1963), p. 39 ; S. F. Librovich, "Petr Lavrovich Lavrov kak redaktor 'Zagranichnago vestnika," Vestnik literatury, 1913, pp. 295-304 and 315-21 ; and N. Belchikov, "'Bibliograf' (1869 g.)," Russkaia shurnalistika: I. Shestidesiatye gody (Moscow, 1930), pp. 133-235. He presented his point of view in expanded form many times in his journal $V$ pered! dvukhnedel'noe obozrenie, esp. nos. 16 (1875) and 26 (1876); and in volume 4 of Vperedl neperiodicheskoe obozrenie, which was published under the separate title Gosudarstvennyi element $v$ budushchem obshchestve (London, 1876). His study of the Paris Commune is also revealing, 18 Marta 1871 goda (Geneva, 1880), especially part 3, on the lessons of the Commune (pp. 206-29). His analysis of the West European socialist movement was 
Taken as a whole, the historical development of Western Europe, in Lavrov's analysis, had created the revolutionary socialist movement. The destruction of the bourgeois mode of production issued naturally from the bourgeois mode of production itself. Capitalism of necessity created the wage laborer and in so doing fostered its own eventual downfall. The victory of socialism in the West was assured by a vital past. Lavrov began his revolutionary career with the assumption that the future belonged to West European scientific socialism, as created by material conditions of West European civilization, as elaborated by Karl Marx and other leading ideologists, and as organized in workers' parties and coordinated within the International Workingmen's Association.

Having agreed to become editor of $V$ pered $!$ and consequently to address himself to the particular problems of Russian socialism, Lavrov confronted a challenging question: What historical basis existed for the hope that rural Russia might join in a European socialist upheaval? The picture was not bright. By comparison with the rich and productive West European historical development, the Russian past seemed barren, but not hopeless.

Lavrov had been influenced by a number of outstanding Russian journalists of the "sixties" who had dealt with the comparative cultural poverty of Russia. N. G. Chernyshevsky wrote of the historical enfeeblement of Russian social and economic life, emphasizing the absence of normal (i.e., West European) capitalistic practices in agriculture and industry and the absence of a strongly developed urban life. The historic evolution of Russia was unprecedented in "geographic Europe," wrote Chernyshevsky. Turkey offered the closest comparison with Russia. But Turkey was culturally and institutionally much more an Asiatic than a European nation. This offered the key to an understanding of Russia: "Asiatic conditions of life, the Asiatic organization of society, the Asiatic order of affairs; everything is said with these words and nothing need be added to them."12 Chernyshevsky, much more than Lavrov, was inclined to idealize the primitive Russian agricultural commune, but the critical appraisal of Russia's past was shared by both. Another associate of Lavrov, Professor P. V. Pavlov, characterized Russia's entire past as a millennium of "slave rule." He noted that quasi-democratic social institutions with considerable developmental potential had existed in the distant past-for example, the federative traditions of Kievan Rus', the municipal

elaborated in his several studies on the history of the socialist movement (see note 15). The most complete statements on the historical origins of the socialist movement in the West were Vzgliad na proshedshee i nastoiashchee russkago sotsializma (St. Petersburg, 1906; first published in Kalendar Narodnoi voli in 1883); and "Istoriia i russkie revoliutsionery" (see note 10).

12. N. G. Chernyshevsky, Polnoe sobranie sochinenii, 16 vols. (Moscow, 1939-53), 5:686-710. On Chernyshevsky's analysis of Russian society, particularly the issue of the "special path" of Russia, see E. S. Vilenskaia, Revoliutsionnoe podpol"e v Rossii (60-e gody $X I X$ v.) (Moscow, 1965), pp. 74-83. 
assembly (veche), the independent patrimonial principality ( $u d e l^{\prime}$ ), and the Zemsky Sobor, an incipient but stunted and short-lived parliamentary body. However, "under the influence of the Mongol Yoke . . . and of retrograde Byzantine despotism, Muscovite state centralism ... gradually displaced the ancient freedoms which had developed in the united Rus' of patrimonial princes and town councils; displaced the regional freedoms of ruling princes and of cities with town councils such as Novgorod and Pskov ... ; displaced ... the freedoms of those who were sworn to the service of boyars; and, finally, displaced .... the freedoms of the peasant commune [obshchina]. From the end of the sixteenth century, the condition of bondage [krepostnoe sostoianie], like a ruinous infection, had enveloped the whole Russian land."13 Thus, in the words of Pavlov, the historical emasculation of Russian social freedom was accomplished.

From the outset Lavrov was critical of Russia's historical legacy. In one of his more widely read studies written in the sixties he complained:

In our past, we have no cause to be carried away by our national theories or by the recollection of political and social habits ingrained in the flesh and blood of our successive generations. We have not had thinkers of world renown, nor sacred, national systems which could be revered by descendants. Neither have we had social traditions such as might nurture the possibility of broad development. Our historians of social life indicate to us that we have developed almost no sense of law, government, or policy. Our clerical historians at every point indicate to us rank ignorance, immorality, deference to form and the letter. . . . And we inherited no moral-political traditions from our history. The veche is but mythology to us, and from the ancient system of military governors [voevodstvo] and the modern guberniia system, from the Muscovite system of gentry rule [mestnichestvo] and the Petersburg bureaucracy [chinovnichestvo], we can extract no rational principles of social life. ${ }^{14}$

Throughout his life Lavrov returned to the issue of Russia's unfruitful historical development. ${ }^{15}$ In his view, the essential historical peculiarity was

13. Quoted in M. K. Lemke, Ocherki osvoboditel'nago dviaheniia "Shestidesiatykh godov" (St. Petersburg, 1908), pp. 7-13.

14. P. L. Lavrov, Filosofia $i$ sotsiologiia: Izbrannye proizvedeniia, 2 vols. (Moscow, $1965), 1: 350$.

15. Lavrov wrote and periodically revised a short study of the condition of the Russian people, "Schety russkogo naroda: Istoricheskii ocherk P. Lavrova" (hectographed copy dated in the 1890s, held in the Museum of Books of the Lenin Library in Moscow). He turned to this issue often in the pages of his journal Vpered! dvnkhnedel'noe obosrenie, esp. nos. 27-29 (1876). In 1879 he wrote on the history of the socialist movement in Russia for the first issue of the German socialist journal Jahrbücher für Sosialwissenschaft und Sozialpolitik; in 1887 he published Natsional'nost' $i$ sotsializm; and in 1892 his 1 storiia, sotsializm i russkoe dvizhenie appeared. Lavrov devoted careful attention to the absence of an historical foundation for liberalism in Russia in Posledovatel'nyia pokoleniia: $V$ pamiat' G. Z. Eliseeva i N.V. Shelgunova (Geneva, 1893). His analysis 
that Russia had not experienced feudalism; she had been cut off from European development by the Mongol invasion in the thirteenth century. Those progressive features of feudalism known to the West were therefore lost to Russia. Russian public institutions which, like the feudal parliaments, might have matured into a real check on the authority of the state were destroyed by what he called the "semi-Asiatic" Muscovite tsardom. ${ }^{16}$ The veche was smashed by the Muscovite tsar acting as an agent of the Tatar khan, and the Zemsky Sobor was discarded by the Petersburg Romanovs, who continued the Muscovite tradition. The Russian Orthodox Church was stripped even of the meager independence that Byzantine traditions might have allowed. The Church became merely an administrative organ, a "passive tool," of central government. Moreover, no concept of legality independent of the crown had developed in the medieval period. As for patrimonial princes, the autocracy divested them of their patrimonies and their independence. Consequently not even the aristocracy could play a real political role in Russia; it had no strength to sustain itself as an independent class. Instead, like other segments of society, the aristocracy became a servitor of the crown. Independent cities were crushed, and thus urban civilization was blighted, the development of commerce and industry stunted, and Russian historical evolution denied the "strong and brilliant" bourgeois political tradition. ${ }^{17}$ The result of this retarded historical evolution was an unbridled and despotic state which ruled by means of one of the most unspeakable bureaucracies in Europe over a primitive, defenseless, rural society.

Lavrov was attentive to the fact that Western Europe was entering a period of further socioeconomic transformation, which threatened to leave Russia even more woefully behind. In 1870 he published a detailed comparison of the levels of economic, political, and social development of several West European states and Russia. ${ }^{18} \mathrm{He}$ noted the relatively backward,

of the origins of the revolutionary situation in Russia was also presented in his commentary published with the Russian translation of A. E. F. Schaeffle's study of socialism, Sushchnost' sotsializma (Geneva, 1881), in his foreword to the Russian translation of Marx's critique of Hegel's philosophy of right, Vvedenie $k$ Kritike filosofii prava Gegelia (Geneva, 1887), in his foreword to the Russian translation of César de Paepe's Obshchestvennaia sluzhba $v$ budushchem obshchestve (London, 1875), and in his centrally important study of the Russian revolutionary movement, "Narodniki 1873-1878 gg." and "Narodniki-propagandisty 1873-1878 gg.," Materialy dlia istorii russkago sotsial'norevoliutsionnago dviaheniia, vol. 10. However, at no point did he deal with the issue so completely as in Vzgliad na proshedshee $i$ nastoiashchee russkago sotsializma (1883) and in "Istoriia i russkie revoliutsionery" (1887) (see note 10). Of great importance is his long, analytical letter to an otherwise unknown correspondent, Alexandra Vasilievna [?], held in the Archive of Russian History and Culture of Columbia University (letter no. 5, dated July 23,1876 ).

16. "Istoriia i russkie revoliutsionery," p. 13.

17. Vzgliad, p. 8.

18. "Evropa i ee sily," Vestnik Evropy, no. 1, 1870, pp. 235-71; no. 2, pp. 691-721; and no. 5, pp. 193-235. 
regressive, and impoverished condition of Russia. State budgets, demographic statistics, and industrial, agricultural, and commercial figures revealed that, while the percentage of the total Russian state budget taken up by military expenditures was the highest of all European states, per capita productive output was next to the lowest (one-fourth that of England), taxes were among the most severe, public savings low, social welfare legislation the poorest, and per capita sugar consumption (a good index of the prosperity and welfare of a population) at the very bottom.

Significantly, Lavrov gave special emphasis to the salutary effects of modern industrial development in Western Europe. And he attacked primitive agricultural landholding systems which served to obstruct modern economic development. He directly related the improvement in general welfare of the masses to increase in productivity, both industrial and agricultural. Lavrov pointed accusingly to low per acre yields of Russian agriculture, aggravatingly low despite the fact that 85 to 90 percent of the Russian population was engaged in agriculture as compared to 12 percent in England. He reminded the reader that the productivity of agriculture depended not only on the gross number of workers on the land but also on the system of land tenure. Thus agricultural production in Russia, "where the most primitive methods and tools still exist," was far below European standards.

Lavrov concluded that the "decline of the West" was a foolish Russian conceit. He rejected the views of the influential F. Ia. Danilevsky, whose recent series of articles, entitled "Russia and Europe," maintained that the West had lost its vitality. ${ }^{19}$ Lavrov predicted the continued and extensive growth of Europe. The accomplishments of the West were highly important for Russians; Russia should aim not at copying insignificant characteristics of Western culture but at assimilating the progressive ones.

By implication Lavrov rejected not only the chauvinistic anti-Westernism of Danilevsky but also the romantic features of Herzen's "Russian socialism," which idealized the peasant commune. In praising the progressive features of Western Europe and condemning "backward" Russia, Lavrov made no exception for the fabled obshchina. Both as a radical in the sixties and as an international socialist thereafter, he brought home the same message: Russia should look to the West; there could be no future for the "rhetorical and false patriotism" expressed by some Russian thinkers. He never forgot that the problems of Russia were distinct and individual, but to him they were a subset of general European social and political problems and were to be solved within that context. ${ }^{20}$

19. Danilevsky's "Rossiia i Evropa" appeared first in the journal Zaria in the spring and summer of 1869; it was published in book form in 1871.

20. The programmatic lead article to the first issue of Vpered l, written by Lavrov, opened and closed with a clear indication that the journal was to be an organ of the inter- 
Despite his bleak analysis of Russia's historical development Lavrov never doubted that Russia was a component part of European civilization. There remained hope for progressive development in Russia. As editor of Vpered! he maintained that one important feature of the objective historical process most recently experienced in the West, the development of the bourgeois mode of production, capitalism, had been under way in Russia since the era of Great Reforms. The freeing of the serfs in 1861 had created the beginnings of a proletariat. He predicted that this beginning ultimately sealed the fate of capitalism and created the conditions for the victory of socialism in Russia just as in Western Europe. ${ }^{21}$

The coming of capitalism, however, did not mean that the barren past could be ignored. Lavrov recognized that there was much more to the "objective" conditions of European social, economic, and political life than capitalist practices, heavy industry, and a proletariat. The complexity of European historical development could not be reduced to such a simple formula. Likewise the emergence in Russia of certain features of the modern European economy was not sufficient to make Russia precisely like the West. He could not accept the naive historical conclusion that once Russia entered the "capitalist phase" she was back on the track, so to speak, and though a bit behind was destined to traverse the same historical landscape that other European states had covered one hundred years earlier. Russia might eventually reach the same final station, but she was not to take precisely the same route. ${ }^{22}$

The remnants of the Russian past were certain to influence the course of future development. There might exist the beginnings of a proletariat, but the Russian factory laborer remained a peasant at heart. Autocracy did not face a strong challenge from any firmly rooted class movement. Bourgeois liberalism had no firm basis for development; it was, as Nicholas II later said for different reasons, a senseless dream. The coming of capitalism did not mean that Russia could expect the same broad social, political, and economic benefits that capitalism had brought to Western Europe. Capitalism arrived in Russia not in its progressive phase but in its latest, most monopolistic, exploitative, and regressive phase. ${ }^{23}$ Regressive capitalism cast an even darker shadow in

national socialist revolutionary movement in the Russian language. Lavrov closed his article with a warning that those who invested their energies in chauvinistic political movements could not expect to serve the future; see "Nasha programma," reprinted most recently in B. S. Itenberg, ed., Revoliutsionnoe narodnichestvo 70-kh godov XIX veka (Moscow, 1964), 1:32.

21. The most direct statement of this analysis appeared in Vpered!, no. 27 (1876), pp. 66-67. See also Vpered! neperiodicheskoe obosrenie, vol. 3, pt. 1, pp. 19-21.

22. See Lavrov's Perezhivaniia doistoricheskago perioda (Geneva, 1898), in which he analyzed historical continuity. Every era carries the indelible traces of that which preceded it.

23. Vperedl, no. 16 (1875). Also see Alexander Gerschenkron, "The Problem of 
Russia because it was so closely tied to the administration, under the "bureaucratic tutelage" of the crown.

And finally, as Lavrov saw it, capitalism came to Russia just as scientific socialism was waxing in the West, just when the socialist revolution was impending. Socialism represented the ultimate progress of European civilization. To struggle for anything less than the most progressive development was both immoral and criminal, especially since the peculiar features of Russia's past assured that capitalism would bring more exploitation and suffering than in the West. In the long haul Russia would experience a socialist revolution, the inevitable product of the growth of capitalism. The "objective conditions" created by the past, however, rendered the politics of waiting for that day unthinkable.

Lavrov was quite unwilling to underwrite the politics of waiting, no matter how sound they might be in theory. His high regard for Marx did not require that he accept Plekhanov's insistence that socialist revolution in Russia would have to await the development of a revolutionary workers' party. Lavrov could not agree with Plekhanov's statement before the founding congress of the Second International in 1889: "The revolution in Russia will triumph as a working-class movement or not at all."24 Lavrov felt that such a view was the equivalent of opting out of the revolutionary movement. $\mathrm{He}$ did not want to postpone action until some distant point of development. He was certain that it was possible to create socialism without precisely retracing the path of English or German development.

Lavrov maintained that Russia could and most certainly should be a part of the general European scene. But she remained distinct, sufficiently affected by her "peculiar" past to prevent direct importation of the politics and programs of the Western movement. Consequently Lavrov rejected both the "Westernizer" and "Slavophilistic" extremes within the Russian movement; for example, he was critical both of his own followers in St. Petersburg who adhered too dogmatically to lessons learned from Marx and of the Bakuninist rebels who sought to build the better future on the unreconstructed instincts of the muzhik. Russia's current condition and future development were strategically similar to that of the West. But the past created quite distinct tactical differences for the Russian revolutionary movement.

Russian revolutionary socialist tactics had to be based on a "peculiar soil" which was the product of Russia's historical development. The significant features of the "peculiar soil" were two in number. First, Russia was almost 90 percent peasant. Second, Russian society was graced by a unique

Economic Development in Russian Intellectual History of the Nineteenth Century," in E. J. Simmons, ed., Continuity and Change in Russian and Soviet Thought (Cambridge, Mass., 1955), p. 31.

24. Quoted in Samuel Baron, Plekhanov: The Father of Russian Marxism (Stanford, 1963), p. 163. 
intelligentsia, who were not a class or administrative unit and, unlike other elements of Russian society, were unflawed by the past.

The Russian peasant was no less intelligent and receptive to the idea of socialism than the worker in the West. In addition, in many regions he was organized in the obshchina, where at least rudimentary habits of solidarity, collective ownership, and collective cultivation survived. Lavrov, however, did not "idealize" the Russian peasant. His obshchina was not the ideal obshchina to which Herzen turned after the bitter disappointment of 1848. Even before his conversion to the cause of revolutionary socialism, Lavrov had expressed his disdain for "primitive agriculture." And he continued to express this view as a revolutionary ideologist. He clearly saw that the rural commune was as compromised and weakened as the other components of society. Like the veche and the sobory, peasant institutions of popular volition had felt the claws of the double-headed eagle; the peasant obshchiny had been to some degree transformed into organs of autocratic fiscal policy. The peasants had preserved some features of the ancient communal landholding system, "but they were deprived of every related organization which would permit them to protect their interests as a class or to take an active part in the political life of the country."25 Certainly some instincts of solidarity and distrust of officialdom survived within the obshchina, but these were "still extremely far from those instincts which would be necessary" in order to establish a scientific socialist community. ${ }^{28}$ The kulak had grown rich within the communal structure. A severe patriarchate squelched free development of the human personality. Consequently feelings of group or class solidarity flourished there only "within the most severe limits."27

Lavrov felt, nonetheless, that peasant communal institutions provided the revolutionary movement with at least one organizational "point of departure."28 He did not mean that Russian revolutionists should turn from European socialism and rest all hope on the socialist instincts of the Russian peasant. To achieve the future socialist state, all these traditional popular and peasant institutions would have to be given "a completely different meaning"; the obshchina would have to be infused patiently and thoroughly with an unshakable consciousness of the tasks of scientific socialism and reorganized along revolutionary socialist lines. ${ }^{29}$

In his use of the term obshchina, Lavrov reflected his preference for the generic over the specific sense of the word; he accepted the socialist goal of

25. "Istoriia i russkie revoliutsionery," p. 12.

26. Vpered!, no. 28 (1876), p. 105.

27. Ibid., no. 27 (1876), p. 70.

28. Lavrov to Alexandra Vasilievna [?], no. 40, written in the first half of 1877 from London (Archive of Russian History and Culture, Columbia University).

29. Lavrov, Gosudarstvennyi element v budushchem obshchestve, p. 120. The italics are mine. 
"communal" organization without involving himself deeply in the question of the Russian agrarian "commune." In his frequently cited programmatic article and throughout Vpered! he called for the socialist transformation of the obshchina, identifying that as "the future of the majority of the Russian population." 30 Similarly "the future of the Slavs as of all mankind consists in this device: science and the obshchina, truth and labor, war against idols and monopoly !'31 He dedicated his journal to the service of "the ideal of a European federation of free obshchiny." He clearly was not limiting his vision to the Russian agricultural obshchina. He employed the word as the Russian equivalent of the French term commune or the German Gemeinde. Such were the terms frequently employed in socialist literature to describe the future federated units of society, whether in the city or in the countryside, whether in Western Europe or in Russia. ${ }^{32}$ Lavrov foresaw that the obshchina (Gemeinde, commune) would be the basic unit of socialist society in Western Europe as well as in Russia.

As an institution promoting the realization of socialism, the Russian agricultural obshchina was never preferable to such workers' organizations as the Northern Union of Russian Workers and the Southern Russian Union of Workers which flourished briefly in the 1870 s under Lavrov's influence. But Lavrov recognized the inescapable and, so far as anyone could see, continual numerical preponderance of the peasantry. A true socialist revolution had to offer the rural population a socialist program. In other words, if the socialist revolution was to triumph in Russia, it would have to do so as an agrarian socialist revolution or not at all. The rural obshchina, despite its weaknesses, could serve as one "point of departure" for launching that socialist revolution.

That is where the intelligentsia came into the picture. The advanced, socialist intelligentsia was the only segment of society capable of preparing thoroughly and with sufficient speed for Russia's participation in the imminent world-wide revolution. Lavrov assigned the intelligentsia no less a task than to make up for the multifold inadequacies of Russian historical development.

30. Itenberg, ed., Revolintsionnoe narodnichestvo, p. 27.

31. Ibid., p. 32. The italics are mine.

32. It should be remembered that the First International formulated a socialist agrarian program. At the Lausanne, Brussels, and Basel congresses of the International, the agrarian question was the major issue. César de Paepe, a man much admired by Lavrov, led the fight for collective ownership in the countryside. The collectivists, with Marx's support, carried the day at the Basel Congress in 1869. J. Ph. Becker, a veteran of the socialist movement, wrote a "Manifesto to the Rural Laborer" in the name of the International. This manifesto stated that the agrarian ideal of the International was rural "communes" (Gemeinden). The manifesto was translated into the major European languages, including Russian. The Russian translation was printed in Narodnoe delo in 1870 and in subsequent separate editions throughout the first half of the 1870 s. The Russian translation neatly renders Gemeinde as obshchina; see Narodnoe delo, no. 6, 1870. Lavrov and many other revolutionists of the 1870s gave their close attention to Narodnoe delo, the most important source of information on the First International in 
He did not feel that a small band of radical intellectuals could shoulder the full burden of Russia's historically crippled social development; the intelligentsia had to organize a mass movement made up of peasants and workers as well as intellectuals. The socialist revolution, above all else, had to be a popular mass movement. But in Russia only the intelligentsia could get such a movement under way and guide it through its early phases. Lavrov did not pioneer the idea of the "dictatorship of the proletariat," but his thought moved naturally in that general direction. Russian society was not ready for socialism, and the revolutionary socialist intelligentsia had to make it so.

In the past, the intelligentsia acting alone had attempted to force the hand of government. But conspiracy was doomed to failure so long as it was without organized ties with the population at large. The Decembrist Revolt of 1825 represented the best example of the inadequacy of the coup d'etat ${ }^{33}$ The failure of the Decembrists did not lie simply in their failure to oust Nicholas I. Even if they had gained power they would have failed, in Lavrov's view, because truly progressive transformation was not possible so long as the people, the narod, were estranged from the leadership of the revolution.

Lavrov launched a spirited attack on the conspiratorial ideology of Peter Tkachev and those who thought like him. Lavrov did not doubt that a conspiratorial or, as it was called, "Jacobin" revolutionary movement could easily "take power" in Russia. Once again Russian historical development was at fault. The structure of the imperial government was purely "mechanical"; it was based neither on a strong and vital webbing of social relationships nor on interlaced and self-sustaining regional or local institutions. There were no vital links between the several component elements in government. Conspirators could neutralize the military and the police, quickly reconstituting them to serve the takeover. The people would be indifferent, as they had always been, to a palace coup. Russian society was historically so devoid of any political initiative that it could not protest in any collective form. Neither rural zemstvos nor urban dumas had strength enough for organized resistance. Conditions for a coup d'état, observed Lavrov, were better in Russia than anywhere in the civilized world. ${ }^{34} \mathrm{~A}$ coup d'état would be relatively easy in Russia, but that did not make it advisable.

The peculiar features of Russia's historical development suggested that "taking power" was not enough if one's objective was to create a socialist society. Lavrov called upon the intelligentsia to overcome the peculiarities of Russia's historical evolution, not to take advantage of them. Acting as what might be called the "vanguard" of the narod, the revolutionary intelligentsia had to organize, augment, give new strength to, and finally transform in a

the Russian language prior to Lavrov's own journal; see "Pis'ma . . . iz Parizha," no. $7-8$, p. 112.

33. Vsgliad, p. 13.

34. Vpered!, no. 28, pp. 97-99. Also see 18 Marta 1871 goda, pp. 208-9. 
"scientific" socialist manner those viable popular habits and groups which existed in Russia. The socialist intelligentsia, in order to hasten the day when Russia could join the global revolutionary transformation, were compelled to reach considerably beyond their nation's native endowment; they had to teach scientific socialism, organize a broadly dispersed, popular (narodnyi) revolutionary socialist party, and foster and encourage the emergence of a leadership from the ranks of the narod themselves. Finally, the intelligentsia had to prepare themselves to take up arms with the people on that "great day" when the international revolution raised the banner of scientific socialism. Although he never addressed himself directly to the question of whether Russia could "go it alone" on the road to socialism, he never failed to place the achievement of socialism in Russia within the international context. The Russian revolutionary movement must stand with pride and strength alongside West European socialist parties. That was the monumental task with which Lavrov charged the Russian intelligentsia. That was the perspective from which he always viewed the Russian revolution.

In this manner Lavrov met the major challenge of his age. He adapted the principal tenets of West European socialism to the needs of the Russian revolutionary movement without either idealizing or ignoring special Russian conditions. The cardinal accomplishment of his ideology was the balance struck between the extremes of dogmatic Westernism and romantic Slavophilism-between, on the one hand, Plekhanov's Procrustean Marxism which minimized the differences between Russia and the West and neglected the peasantry, and, on the other hand, Sergei Kravchinsky's naive agrophilia which advised revolutionists to abandon European socialism altogether and rely solely on the instincts of the Russian muzhik. ${ }^{35}$ Lavrov's perspective gave him insight into the weaknesses of Russia and convinced him that historical backwardness and impoverishment could not be erased simply by the inroads of capitalism, by direct application of revolutionary patterns developed for other environments, by heroic, nativistic bunt (rebellion), or by seizure of power.

How, then, was the backwardness of Russia to be overcome? In essence, Lavrov answered that the march of time would eventually overcome Russia's cruel historical fate and she would be reunited with Europe in socialism, the

35. In a letter written to Lavrov in early spring 1882 Plekhanov discussed his unwillingness to cooperate with other Russian revolutionists on the editorial board of the journal Vestnik "Narodnoi voli." In particular he complained that there was such a gulf between himself and Kravchinsky that no reconciliation was possible: "I am ready to make a Procrustean bedstead out of Kapital for all the collaborators on Vestnik 'Narodnoi voli" " Deich, ed., G.V. Plekhanov: Materialy dlia biografii, p. 93. A few years earlier Kravchinsky shocked many of his colleagues by asserting, "The time has come to remove the German garb from socialism and to clothe it in the Russian peasant blouse [sermiagu]"; quoted in B. P. Kozmin, Iz istorii revoliutsionnoi mysli v Rossii (Moscow, 1961), p. 642 . 
final station of historical development. But he also answered that waiting on the march of time was unnecessary. Russia could join the world revolution if the intelligentsia could broadcast socialist consciousness across the land and mold a vast socialist organization through propaganda (ideological education) and agitation (organized revolutionary action).

Although he urged that patterns evolved in the West should not be given universal validity and applied artificially to Russia, he did not expect that Russia, with her peculiar past, would experience a peculiar future. He accepted a vision of the future which corresponded to that of the West European socialist movement. Lavrov knew that the European vision and movement were the products of a rich historical development. He knew that Russian development differed critically from the European experience. His own analysis seemed to suggest that Russia's special past had to result in a special future. But he continued to feel that Russia could be made ready for the European revolution in the not too distant future. He failed to take into account the limitations of the kind of social engineering he asked the intelligentsia to perform in the special Russian environment. The tactic he suggested to the intelligentsia was nothing less than to make up for the long-term deficiencies of the Russian past, to make Russia ready for the socialist future. He formulated the differences between Russia and the West in terms of tactics when his own analysis suggested that the differences were greater. He realized, but sometimes forgot, that where a society can go is determined largely by where it has been.

Ultimately there was in his socialism a strong streak of idealism. It revealed itself both in his faith in the power and effectiveness of revolutionary organization and socialist education in Russia and in his indefatigable faith in a socialist future for all Europe. His Last Will and Testament holds a separate paragraph wherein he predicted that the day of success was just ahead, for Western Europe and for Russia as well. ${ }^{36}$ In the last months of his life, against all odds, he willed to the Russian revolutionary movement his expectation, his dream of impending victory. ${ }^{37}$ In that sense he was an idealist. But his was an idealism not particularly Russian or uniquely populist. His was an idealism indigenous to the socialist movement of the Western world.

36. Lavrov's Last Will and Testament, which he wrote in French in the last year of his life (1899), is in the Nikolaevsky Collection at the Hoover Institution.

37. Two years after Lavrov's death, Lenin might be said to have availed himself of the Lavrov inheritance in his pamphlet, "What Is To Be Done?" With reference to Marx's preface to "A Contribution to a Critique of Political Economy," Lenin addressed himself to the problem of planning a modern socialist revolution in backward Russia. Marx himself had stated explicitly that mankind always takes up only such problems as it can solve. Social problems arise only when the material conditions necessary for their solution already exist. There was some question whether the material conditions for socialism on a Marxist pattern existed in Russia. Lenin's solution to this problem was, "We must dream!" ("nam nuzhno mechtat' '"). See Lenin, Sochineniia, 3rd ed. (Moscow, 1937), 4: 492-93. 